\title{
Meta-topolin improved micropropagation in Syzygium cumini and acclimatization to ex vitro conditions
}

\author{
A. NAAZ ${ }^{1,3}$, S.A. HUSSAIN ${ }^{1}$, M. ANIS ${ }^{1 *}$, and A.A. ALATAR ${ }^{2}$ \\ Plant Biotechnology Laboratory, Department of Botany, Aligarh Muslim University, Aligarh 202002, India ${ }^{1}$ \\ Department of Botany and Microbiology, Faculty of Science, King Saud University, Riyadh 11451, Saudi Arabia ${ }^{2}$ \\ Department of Physics, Indian Institute of Technology, Patna 801103, India ${ }^{3}$
}

\begin{abstract}
An efficient micropropagation system was developed for a recalcitrant woody tree Syzygium cumini (L.) Skeels using nodal explants excised from 15-d-old aseptic seedlings. The explants were employed on an Murashige and Skoog (MS) medium supplemented with different concentrations $(1.0-10.0 \mu \mathrm{M})$ of cytokinins, such as benzyladenine (BA), kinetin (Kin), meta-topolin (mT), or 2-isopentyl adenine (2ip), either alone or in combination with different concentrations $(1.0-3.0 \mu \mathrm{M})$ of auxins, such as indole-3-acetic acid (IAA), indole-3-butyric acid (IBA), or $\alpha$-naphthalene acetic acid (NAA). Of the cytokinins tested, mT proved to be best for shoot bud induction and proliferation. Among the tested combinations, a maximum regeneration $(90 \%)$ with a mean shoot number of $25.33 \pm 0.33$ and a shoot length of $5.20 \pm 0.11 \mathrm{~cm}$ were recorded on the MS medium containing $5.0 \mu \mathrm{M} \mathrm{mT}+2.0 \mu \mathrm{M}$ NAA after 12 weeks of incubation. Further 4-week incubation on optimum $5.0 \mu \mathrm{M} \mathrm{mT}$ before transfer to a secondary medium consisting of $\mathrm{MS}+5.0 \mu \mathrm{M}$ $\mathrm{BA}+2.0 \mu \mathrm{M}$ NAA yielded up to 51 microshoots with an average length $(6.53 \mathrm{~cm})$. For in vitro rooting, healthy shoots (about $5 \mathrm{~cm}$ ) were excised and incubated on the half or full strength MS medium enriched with different concentrations $(1-7.5 \mu \mathrm{M})$ of NAA. A substantial increase in rhizogenic competency $(15 \%)$ was observed in shoots raised on a medium with $\mathrm{mT}$ with a mean root number of $6.33 \pm 0.10$ and a mean length of $5.13 \pm 0.21 \mathrm{~cm}$ on the half MS supplemented with $5.0 \mu \mathrm{M}$ NAA after 4 weeks. A maximum of $95 \%$ plantlets regenerated on the medium with mT was successfully acclimatized and established in earthen pots under field conditions. The consistent increases in activities of superoxide dismutase, catalase, glutathione reductase, and ascorbate peroxidase during acclimatization indicate that $\mathrm{mT}$ raised plantlets response well to the stress induced by ex vitro conditions.
\end{abstract}

Additional key words: ascorbate peroxidase, benzyladenine, catalase, glutathione reductase, $\alpha$-naphthalene acetic acid, superoxide dismutase.

\section{Introduction}

Syzygium cumini L. (Myrtaceae) is a valuable medicinal tree commonly known as jamun in the Indian subcontinent. It is a rich source of bioactive compounds like alkaloids, flavonoids, sterols, saponins, tannins, and volatile oils. The tree is naturally propagated through seeds, but poor seed viability, low germination rate and

fast fungal contamination on germinating seeds restrict the production of healthy plant stocks. Micropropagation of this recalcitrant species has been reported earlier through juvenile (Yadav et al. 1990, Jain and Babbar 2000, Rathore et al. 2004) and mature tissues (Naaz et al. 2014). Continuous research in plant tissue culture

Submitted 10 April 2018, last revision 17 August 2018, accepted 1 October 2018.

Abbreviations: APX - ascorbate peroxidase; BA - benzyladenine; CAT - catalase; GR - glutathione reductase; IAA - indole-3-acetic acid; IBA - indole-3-butyric acid; 2ip - isopentyl adenine; Kin - kinetin; MDA - malondialdehyde; mT - meta-topolin; MS - Murasige and Skoog; NAA - $\alpha$-naphthalene acetic acid; PGR - plant growth regulator;SOD - superoxide dismutase.

Acknowledgements: The authors extend their appreciation to the International Scientific Partnership Program (ISPP) at King Saud University for funding this project (ISSPP \# 0082). The award of the UGC-BSR Faculty Fellowship (2017) to M.A. is duly acknowledged. A.N. gratefully acknowledges the financial assistance provided by the Science and Engineering Research Board (SERB)/Department of Science and Technology Govt. of India, New Delhi, India, for the award of National Post-doc Fellowship (NPDF) vide PDF/2016/003254.

* Corresponding author; e-mail: anism1@rediffmail.com 
tries to reduce physiological disorders during in vitro growth and during an acclimatization phase (Aremu et al. 2012). However, no reports are available on comparative analysis of a novel aromatic cytokinin meta-topolin (mT) and benzyladenine (BA) on protection of juvenile plantlets against stresses induced by ex-vitro transfer.

\section{Materials and methods}

In vitro regeneration: Seeds were harvested from fresh ripened fruits in June/July from a tree planted in the University campus. These were washed thoroughly for half an hour under running tap water followed by $20 \mathrm{~min}$ immersion in $5 \%(\mathrm{~m} / \mathrm{v})$ Bavistin (BASF, Mmbai, India) on a shaker. Further, the seeds were treated with $5 \%$ (v/v) Teepol (Qualigens Fine Chemical, Mumbai, India) for $10 \mathrm{~min}$ followed by thorough washing and treating with $10 \mathrm{mg} \mathrm{dm}^{-3}$ polyvinylpyrollidone (PVP) for $6 \mathrm{~h}$ to control phenol exudation. Before inoculation onto a regeneration medium, the seeds were disinfected with 0.1 $\%(\mathrm{~m} / \mathrm{v}) \mathrm{HgCl}_{2}$ solution for $5 \mathrm{~min}$ and finally rinsed few times with sterilized deionized water. Murashige and Skoog (1962; MS) medium fortified with various plant growth regulators (PGRs) at varying concentrations were used. Sucrose $(3 \%, \mathrm{~m} / \mathrm{v})$ was used as a carbon source, and $\mathrm{pH}$ of the medium was adjusted to 5.8 using $1 \mathrm{M} \mathrm{HCl}$ or $1 \mathrm{M} \mathrm{NaOH}$ before addition of $0.8 \%(\mathrm{~m} / \mathrm{v})$ agar as a gelling agent. Autoclaving the medium was carried out at $121^{\circ} \mathrm{C}$ for $15 \mathrm{~min}$.

Nodal segments were excised from 15-d-old aseptic seedlings and incubated in a growth chamber at a temperature of $25 \pm 2{ }^{\circ} \mathrm{C}$, a 16 -h photoperiod, and an irradiance of $50 \mu \mathrm{mol} \mathrm{m} \mathrm{m}^{-2} \mathrm{~s}^{-1}$ provided by cool white fluorescent lamps ( 2 tubes, each of 40 Watt, Philips, New Delhi, India). Culture media without any PGR acted as a control. Explants were placed vertically on basal MS media augmented with BA, kinetin (Kin), isopentyl adenine (2iP), and $\mathrm{mT}$ in varying concentrations (1.0, 2.5, $5.0,7.5$, or $10.0 \mu \mathrm{M}$ ) for shoot induction. A preliminary experiment was carried out with the MS basal medium enriched with different concentrations of BA, Kin, 2iP, mT singly $(1.0-10.0 \mu \mathrm{M})$ or in combination with auxins $[1.0,2.0$, or $3.0 \mu \mathrm{M}$ indole-3-acetic acid (IAA), indole-3butyric acid (IBA) or $\alpha$ - naphthalene acetic acid (NAA)]. The second phase of experiment was conducted by giving 4-week-mT exposure to the explants before transferring them to a secondary medium consisting of MS augmented with different concentrations of BA (1.0, 2.5, $5.0,7.5$, or $10.0 \mu \mathrm{M})$ alone or in combination with auxins IAA, IBA or NAA $(1.0,2.0$, or $3.0 \mu \mathrm{M})$. All experiments were repeated thrice and 10 replicates were employed for each concentration. The growth parameters were recorded after four weeks. Subculturing onto a similar fresh medium was done every three weeks.

In vitro rhizogenesis and acclimatization: Healthy and
Therefore, the aim of present communication was to compare $\mathrm{mT}$ and $\mathrm{BA}$ during regeneration of shoots from nodal explants, their rooting, and subsequent acclimatization. We focused not only on growth but also on physiological parameters and especially on antioxidant activity during acclimatization.

elongated shoots $(5 \mathrm{~cm})$ were excised from the cultures and transplanted to a rooting medium containing the full or half strength MS medium supplemented with various concentrations of NAA $(1.0,2.5,5.0$, or $7.5 \mu \mathrm{M})$.Wellrooted shoots were removed and washed thoroughly under running water to remove any adherent particles, transferred to Thermocol cups containing sterile Soilrite (Keltech Energies, Bangalore, India), and covered with transparent polythene bags with few holes to ensure a high air humidity. The covered shoots were also sprayed with a half strength MS salt solution (without vitamins) for two weeks, and the number of holes was gradually increased. The acclimatized plantlets were transferred to pots containing normal soil after eight weeks and maintained in a greenhouse prior to transferring to the field. Percentages of rooting and successful acclimatization of regenerants raised on the medium with $\mathrm{mT}$ or BA were evaluated. Several potting substrates (Soilrite, Vermiculite, and garden soil) were also used during acclimatization of BA and $\mathrm{mT}$ raised regenerants, and the data were recorded after $40 \mathrm{~d}$ of acclimatization.

Evaluation of antioxidant enzyme activities: Fresh leaf tissue $(0.5 \mathrm{~g})$ collected from acclimatized plantlets was homogenized with $0.11 \mathrm{~g}$ of ethylenediamine-tetraacetic acid (EDTA) using a pre-chilled mortar and pestle and centrifuged at $15000 \mathrm{~g}$ for $20 \mathrm{~min}$. The whole procedure was carried out in the dark at $4{ }^{\circ} \mathrm{C}$.

Superoxide dismutase (SOD) ctivity was measured by the method of Dhindsa et al. (1981). The activity in the supernatant was assayed by its ability to inhibit the photochemical reduction of nitrobluetetrazolium (NBT). A reaction mixture consisted of $1.5 \mathrm{~cm}^{3}$ of $0.5 \mathrm{mM}$ phosphate buffer $(\mathrm{pH} 7.5), 0.2 \mathrm{~cm}^{3}$ of methionine, $0.1 \mathrm{~cm}^{3}$ of the enzyme extract with an equal amount of $1 \mathrm{M} \mathrm{Na}_{2} \mathrm{CO}_{3}, 2.25 \mathrm{mM}$ NBT solution, $3.0 \mathrm{mM}$ EDTA, $60 \mu \mathrm{M}$ riboflavin and $1.0 \mathrm{~cm}^{3}$ of double distilled $\mathrm{H}_{2} \mathrm{O}$ in test tubes was incubated under a $15 \mathrm{~W}$ fluorescent lamp at $25-28{ }^{\circ} \mathrm{C}$ for $10 \mathrm{~min}$. Absorbance of samples was recorded at $560 \mathrm{~nm}$ against a non-irradiated blank using a UV-Pharma Spec 1700 spectrophotometer (Shimadzu, Kyoto, Japan). One unit of SOD activity corresponded to a $50 \%$ reduction in NBT photooxidation.

Catalase (CAT) activity was determined following the method of Aebi (1984) by monitoring the disappearance of $\mathrm{H}_{2} \mathrm{O}_{2}$ according to a decrease in absorbance at $240 \mathrm{~nm}$. A reaction was carried for $5 \mathrm{~min}$ in a final volume of 
$2 \mathrm{~cm}^{3}$ of reaction mixture containing a $0.5 \mathrm{mM}$ phosphate buffer ( $\mathrm{pH}$ 7.0). Activity was calculated by using a coefficient of absorbance $(\varepsilon)$ of $0.036 \mathrm{mM}^{-1} \mathrm{~cm}^{-1}$.

Ascorbate peroxidase (APX) activity was determined using the method proposed by Bergmeyer et al. (1974). It measures the oxidation of pyrogallol to purpurogallin, and this reaction was monitored by change in absorbance at $420 \mathrm{~nm}$.

Glutathione reductase (GR) activity was determined by the method of Foyer and Mullineaux. (1994) modified by Rao (1992). It was monitored by the glutathione dependent oxidation of NADPH at its absorption maximum at $340 \mathrm{~nm}$. The activity was calculated by using $\varepsilon$ of $6.2 \mathrm{mM}^{-1} \mathrm{~cm}^{-1}$.

Lipid peroxidation and $\mathrm{H}_{2} \mathrm{O}_{2}$ content: Malondialdehyde (MDA) content as a characteristics of membrane lipid peroxidation was determined using the modified protocol of Cakmak and Horst (1991). Leaf tissue $(0.5 \mathrm{~g})$ was homogenized with $5 \mathrm{~cm}^{3}$ of $0.1 \%$ $(\mathrm{m} / \mathrm{v})$ trichloroacetic acid and centrifuged at $15000 \mathrm{~g}$ for $5 \mathrm{~min}$. A mixture of $1 \mathrm{~cm}^{3}$ of the supernatant with $4 \mathrm{~cm}^{3}$ $0.5 \%(\mathrm{~m} / \mathrm{v})$ thiobarbituric acid was kept in boiling water for $30 \mathrm{~min}$, immediately cooled down in an ice bath before being centrifuged again at $10000 \mathrm{~g}$ for $30 \mathrm{~min}$. The absorbance of the supernatant was determine at

\section{Results and discussion}

Any sign of growth or differentiation was not observed on the MS medium without PGRs. However, supplementation of different PGRs to the MS medium facilitated shoot bud induction after one week of incubation. Among the tested cytokinins, BA and mT showed a good morphogenesis and better regeneration rates than Kin and 2ip. After 12 weeks of incubation, explants on $5.0 \mu \mathrm{M} \quad \mathrm{mT}$ exhibited the highest regeneration frequency $(71 \%)$ with a maximum mean shoot number of $15.66 \pm 0.88$ and a mean shoot length of $3.86 \pm 0.88 \mathrm{~cm}$, whereas BA at the same tested concentration was slightly less effective and yielded $13.00 \pm 1.10$ shoots with a mean shoot length of $3.43 \pm$ $0.03 \mathrm{~cm}$ (Table 1).

A critical balance between cytokinin and auxin concentrations effectively influenced meristematic activity in the axilliary buds. Different concentrations $(1.0-3.0 \mu \mathrm{M})$ of IAA, IBA and NAA were tested with optimized concentrations of cytokinins. A significant improvement in growth parameters was observed in all cytokinin and auxin combinations, but NAA gave the best response followed by IAA and IBA. Among the tested combinations, $5.0 \mu \mathrm{M} \mathrm{mT}+2.0 \mu \mathrm{M}$ NAA gave a $79 \%$ response with a maximum mean shoot number of $25.33 \pm 0.23$ per explant and a mean shoot length of $5.20 \pm 0.11 \mathrm{~cm}$ after 12 weeks of culture (Table 2). For
$532 \mathrm{~nm}$.

Hydrogen peroxide estimation was carried out following the protocol described by Alexieva et al. (2001). A leaf sample (50 mg) was homogenized in a $50 \mathrm{mM}$ potassium phosphate buffer $(\mathrm{pH} 6.5)$, and centrifuged at $12000 \mathrm{~g}$ for $25 \mathrm{~min}$. All the extractions and estimations were done under a minimal irradiance. The absorbance of the supernatant was measured at $410 \mathrm{~nm}$.

Proline content was measured by the method given by Carillo et al. 2008. Fresh leaf samples (50 mg) were homogenized with $0.4-1 \mathrm{~cm}^{3}$ of an ethanol:water (40:60, $\mathrm{v} / \mathrm{v})$ mixture and left overnight at $4{ }^{\circ} \mathrm{C}$. The mixture was centrifuged at $14000 \mathrm{~g}$ for $5 \mathrm{~min}$, the supernatant was collected and used for proline content estimation, and the pellet obtained was discarded.

tatistical analysis: All the experiments were done at a completely randomized design with 10 replicates for each treatment. Data were subjected to one-way analysis of variance (ANOVA) using SPSS v. 16 (SPSS Inc., Chicago, USA). The Duncan multiple range test at $\alpha=0.05$ was used to check the significance of differences. The results were expressed as means \pm SEs of three repeated experiments. example, $\mathrm{mT}$ in combination with IBA yielded a maximum of $20.00 \pm 0.33$ shoots per explant. The cultures raised on $\mathrm{mT}$ appeared green and healthy, whereas BA mediated cultures showed some discrepancies in the form of hyperhydricity. However, 2ip and Kin mediated cultures exhibited a poor morphological response either alone or in combinations with auxins. The same morphogenic anomalies during the in vitro growing phase has been documented and reported in Spathiphyllum floribundum (Werbrouck et al. 1996).

The effect of $\mathrm{mT}$ exposure on the regeneration potential of nodal explants was also explored separately. A $97 \%$ regeneration potential was exhibited when $\mathrm{mT}$ $(5.0 \mu \mathrm{M})$ exposed nodal explants were subsequently transferred onto a secondary medium enriched with already optimized concentration of BA $(5.0 \mu \mathrm{M})$ with different concentrations $(1.0-3.0 \mu \mathrm{M})$ of auxins IAA, IBA, and NAA. It not only increased shoot regeneration but also eliminated the negative effect of BA alone on growing cultures. A maximum shoot number of $44.00 \pm$ 0.57 with a mean shoot length of $4.76 \pm 0.14 \mathrm{~cm}$ was obtained 8 weeks after transfer (Table 3 ). On subsequent sub-culturing to a similar fresh medium, the shoot number got increased, but shoots had short internodes and small leaves. However, after transfer to $\mathrm{MS}+5.0 \mu \mathrm{M}$ $\mathrm{BA}+2.0 \mu \mathrm{M}$ NAA, the increase in shoot number and 
shoot length were observed. Among the tested auxins with BA, NAA showed a better synergistic effect on shoot morphogenesis than other auxins in the same concentration. A maximum of $51.00 \pm 0.33$ shoots with an average shoot length of $6.53 \pm 0.03 \mathrm{~cm}$ was recorded 8 weeks after incubation on a secondary medium (MS + $5.0 \mu \mathrm{M}$ BA $+2.0 \mu \mathrm{M}$ NAA), however, the same concentration of BA with IAA and IBA was least effective (Table 3). Further shoot complications like vitrification, chlorosis, and leaf abscission that were observed in BA mediated cultures were completely arrested in $\mathrm{mT}$ exposed cultures (Fig. $1 A$ ). Our findings are in accordance with the earlier reports in other plants like Curcuma longa (Salvi et al. 2002), Aloe polyphylla (Bairu et al. 2007), banana cv. Williams (Aremu et al. 2012b), and Prunus (Gentile et al. 2014). Presence of a hydroxyl group in $\mathrm{mT}$ may be the reason of excellence for healthy regeneration (Bairu et al. 2008, Koszeghi et al. 2014, Amoo et al. 2011). A real and actual reason for such a brilliant role of $\mathrm{mT}$ is not yet known and needs a deeper research.

Further, mT exposed cultures did not lose their regeneration capacity even after 12 sub-culture passages. Thus, cultures could easily be maintained for more than a year by just frequent sub-culturing onto the same fresh medium after every three weeks. The repeated subculture maintains juvenility, which in turn promotes better rooting (Ecomomou and Read 1986). This approach of increasing the yield of shoots at an enhanced pace was adopted earlier for other woody plants (Anis et al. 2010,

Table 1. Effect of cytokinins on in vitro shoot regeneration from aseptic nodal explants on a Murashige and Skoog medium 12 weeks after incubation. Means \pm SEs, $n=3$, values denoted with different letters are significantly different $(P \leq 0.05)$ using the Duncan multiple range test. BA - benzyladenine, Kin - kinetin, 2iP - isopentyl adenine, mT - meta-topolin.

\begin{tabular}{|c|c|c|c|c|c|c|}
\hline BA & Kin & 2ip & $\mathrm{mT}$ & Response [\%] & Shoot number [explant ${ }^{-1}$ ] & Shoot length $[\mathrm{cm}]$ \\
\hline 1.0 & & & & 49 & $4.33 \pm 0.33^{\mathrm{fg}}$ & $1.80 \pm 0.11^{\mathrm{jk}}$ \\
\hline 2.5 & & & & 55 & $6.33 \pm 0.66^{\mathrm{de}}$ & $2.63 \pm 0.12^{\mathrm{efg}}$ \\
\hline 5.0 & & & & 68 & $13.00 \pm 1.10^{\mathrm{b}}$ & $3.43 \pm 0.03^{\mathrm{b}}$ \\
\hline 7.5 & & & & 63 & $9.33 \pm 0.33^{c}$ & $3.13 \pm 0.08^{c}$ \\
\hline \multirow[t]{16}{*}{10.0} & & & & 57 & $7.33 \pm 0.33^{\mathrm{d}}$ & $2.50 \pm 0.11^{\mathrm{fg}}$ \\
\hline & 1.0 & & & 33 & $2.66 \pm 0.33^{\text {ghi }}$ & $1.26 \pm 0.17^{\mathrm{mn}}$ \\
\hline & 2.5 & & & 48 & $4.66 \pm 0.88^{f g}$ & $2.80 \pm 0.11^{\mathrm{de}}$ \\
\hline & 5.0 & & & 59 & $6.00 \pm 0.57^{\mathrm{de}}$ & $2.06 \pm 0.06^{\mathrm{ij}}$ \\
\hline & 7.5 & & & 51 & $3.66 \pm 0.33^{\mathrm{gh}}$ & $1.73 \pm 0.03^{\mathrm{k}}$ \\
\hline & 10.0 & & & 43 & $3.33 \pm 0.88^{\mathrm{ghi}}$ & $1.13 \pm 0.08^{\mathrm{mn}}$ \\
\hline & & 1.0 & & 29 & $2.33 \pm 0.16^{\mathrm{ghi}}$ & $1.03 \pm 0.08^{\mathrm{n}}$ \\
\hline & & 2.5 & & 41 & $4.66 \pm 0.66^{\mathrm{fg}}$ & $1.36 \pm 0.03^{\mathrm{lm}}$ \\
\hline & & 5.0 & & 35 & $2.46 \pm 0.33^{\mathrm{ghi}}$ & $2.13 \pm 0.08^{\mathrm{hi}}$ \\
\hline & & 7.5 & & 27 & $2.33 \pm 0.33^{\mathrm{hi}}$ & $1.56 \pm 0.12^{\mathrm{kl}}$ \\
\hline & & 10.0 & & 23 & $1.66 \pm 0.33^{\mathrm{j}}$ & $1.03 \pm 0.08^{\mathrm{n}}$ \\
\hline & & & 1.0 & 53 & $6.00 \pm 0.57^{\mathrm{de}}$ & $2.40 \pm 0.11^{\mathrm{gh}}$ \\
\hline & & & 2.5 & 61 & $9.33 \pm 0.88^{c}$ & $2.76 \pm 0.88^{\mathrm{ef}}$ \\
\hline & & & 5.0 & 71 & $15.66 \pm 0.88^{\mathrm{a}}$ & $3.86 \pm 0.88^{\mathrm{a}}$ \\
\hline & & & 7.5 & 65 & $10.66 \pm 0.88^{c}$ & $3.46 \pm 0.12^{\mathrm{b}}$ \\
\hline & & & 10.0 & 62 & $7.33 \pm 0.33^{\mathrm{d}}$ & $3.06 \pm 0.66^{\mathrm{cd}}$ \\
\hline
\end{tabular}

Table 2. Effect of $5.0 \mu \mathrm{M}$ meta-topolin with different auxins on morphogenic response of nodal explants 12 weeks after incubation. Means \pm SEs, $n=3$, values denoted with different letters are significantly different $(P \leq 0.05)$ using the Duncan multiple range test. IAA - indole-3-acetic acid, IBA - indole-3-butyric acid, NAA - $\alpha$-naphthalene acetic acid.

\begin{tabular}{|c|c|c|c|c|c|}
\hline IAA & IBA & NAA & Response [\%] & Shoot number $\left[\right.$ exlant $\left.^{-1}\right]$ & Shoot length $[\mathrm{cm}]$ \\
\hline $\begin{array}{l}1.0 \\
2.0 \\
3.0\end{array}$ & $\begin{array}{l}1.0 \\
2.0 \\
3.0\end{array}$ & $\begin{array}{l}1.0 \\
2.0 \\
3.0\end{array}$ & $\begin{array}{l}66 \\
73 \\
67 \\
70 \\
75 \\
69 \\
73 \\
79 \\
61\end{array}$ & $\begin{array}{l}18.00 \pm 0.57^{\mathrm{e}} \\
22.33 \pm 0.33^{\mathrm{b}} \\
19.03 \pm 0.33^{\mathrm{de}} \\
17.33 \pm 0.88^{\mathrm{e}} \\
20.00 \pm 0.00^{\mathrm{cd}} \\
17.66 \pm 0.33^{\mathrm{e}} \\
21.66 \pm 1.20^{\mathrm{bc}} \\
25.33 \pm 0.33^{\mathrm{a}} \\
23.00 \pm 1.00^{\mathrm{b}}\end{array}$ & $\begin{array}{l}3.66 \pm 0.12^{\mathrm{ef}} \\
4.13 \pm 0.06^{\mathrm{c}} \\
3.86 \pm 0.08^{\mathrm{de}} \\
3.56 \pm 0.12^{\mathrm{f}} \\
3.93 \pm 0.03^{\mathrm{cd}} \\
3.53 \pm 0.03^{\mathrm{f}} \\
4.50 \pm 0.11^{\mathrm{b}} \\
5.20 \pm 0.11^{\mathrm{a}} \\
4.70 \pm 0.05^{\mathrm{b}}\end{array}$ \\
\hline
\end{tabular}


Table 3. Effect of 4-week exposure of explants to $5.0 \mu \mathrm{M}$ meta-topolin in a Murashige and Skoog (MS) medium on a subsequent regeneration on an MS medium supplemented with various concentrations of benzyladenine alone or in combination with different auxins for further 8 weeks. Means \pm SEs, $n=3$, values denoted with different letters are significantly different $(P \leq 0.05)$ using the Duncan multiple range test. For abbreviations, see Table 2.

\begin{tabular}{|c|c|c|c|c|c|c|}
\hline $\mathrm{BA}$ & IAA & IBA & NAA & Response [\%] & Shoot number exlant $^{-1}$ ] & Shoot length $[\mathrm{cm}]$ \\
\hline 1.0 & & & & 78 & $30.33 \pm 0.66^{\mathrm{h}}$ & $3.13 \pm 0.18^{\mathrm{h}}$ \\
\hline 2.5 & & & & 81 & $35.66 \pm 0.66^{\mathrm{g}}$ & $4.20 \pm 0.10^{\mathrm{fg}}$ \\
\hline 5.0 & & & & 83 & $44.00 \pm 0.57^{\mathrm{de}}$ & $4.76 \pm 0.14^{\mathrm{e}}$ \\
\hline 7.5 & & & & 79 & $38.33 \pm 0.33^{\mathrm{f}}$ & $4.33 \pm 0.08^{f}$ \\
\hline 10.0 & & & & 75 & $32.33 \pm 0.66^{\mathrm{h}}$ & $3.83 \pm 0.03^{\mathrm{g}}$ \\
\hline 5.0 & 1.0 & & & 77 & $39.66 \pm 0.33^{\mathrm{f}}$ & $3.93 \pm 0.06^{\mathrm{fg}}$ \\
\hline 5.0 & 2.0 & & & 84 & $45.66 \pm 0.66^{\mathrm{cd}}$ & $5.36 \pm 0.06^{\mathrm{c}}$ \\
\hline 5.0 & 3.0 & & & 79 & $42.33 \pm 0.33^{\mathrm{e}}$ & $4.83 \pm 0.08^{\mathrm{de}}$ \\
\hline 5.0 & & 1.0 & & 86 & $43.00 \pm 1.15^{\mathrm{e}}$ & $4.10 \pm 0.10^{\mathrm{fg}}$ \\
\hline 5.0 & & 2.0 & & 91 & $47.33 \pm 0.88^{\mathrm{bc}}$ & $5.86 \pm 0.08^{b}$ \\
\hline 5.0 & & 3.0 & & 83 & $48.00 \pm 1.15^{\mathrm{bc}}$ & $5.23 \pm 0.12^{\mathrm{cd}}$ \\
\hline 5.0 & & & 1.0 & 93 & $48.66 \pm 1.45^{b}$ & $5.16 \pm 0.38^{\mathrm{cd}}$ \\
\hline 5.0 & & & 2.0 & 97 & $51.00 \pm 0.33^{\mathrm{a}}$ & $6.53 \pm 0.03^{\mathrm{a}}$ \\
\hline 5.0 & & & 3.0 & 91 & $47.66 \pm 0.66^{\mathrm{bc}}$ & $5.80 \pm 0.15^{\mathrm{b}}$ \\
\hline
\end{tabular}

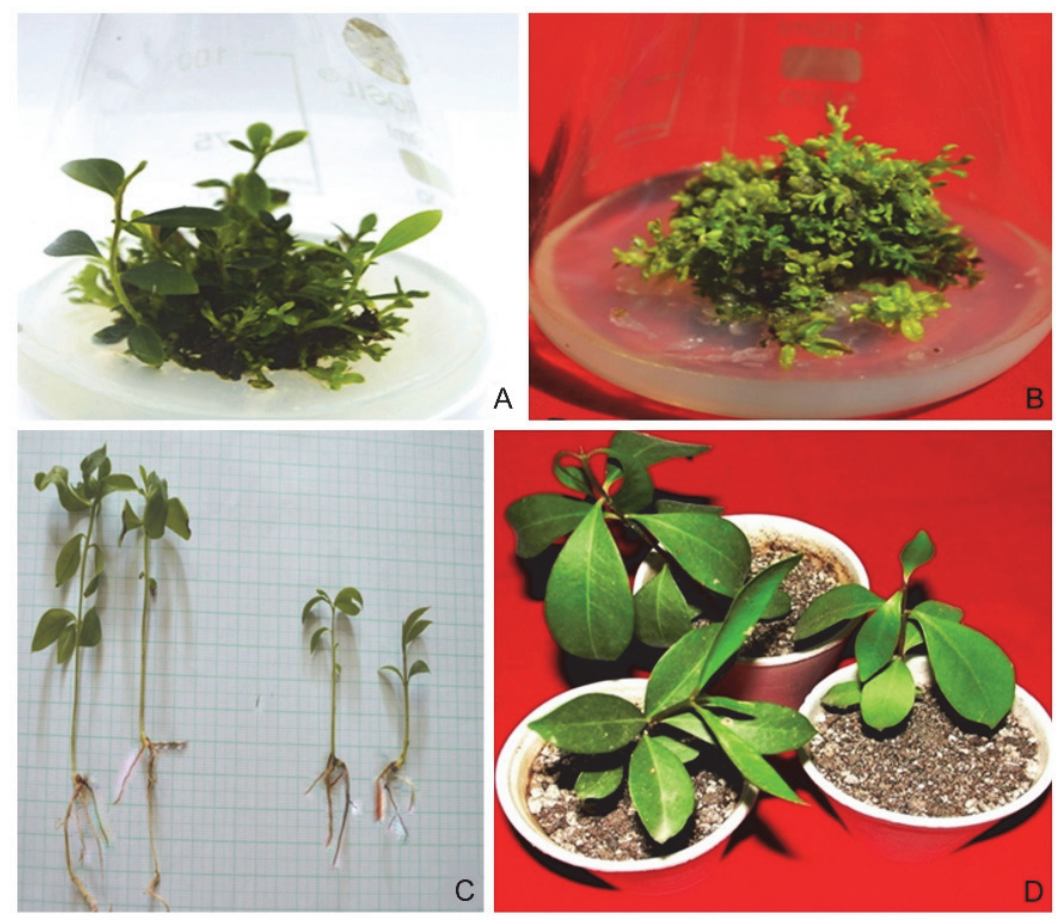

Fig. 1. $A$ - Explants were firstly exposed to $5.0 \mu \mathrm{M}$ meta-topolin (mT) in a Murashige and Skoog (MS) medium for 4 weeks and then grown on the $\mathrm{MS}+5.0 \mu \mathrm{M}$ benzyladenine (BA) for 8 weeks. $B$ - Proliferation and elongation of mT exposed explants on the MS + $5.0 \mu \mathrm{M}$ BA $+2.0 \mu \mathrm{M}$ NAA; 8 weeks after transfer. $C$ - In vitro rooting of mT mediated shoots on a half (on the left) or full (on the right) strength $\mathrm{MS}$, both with $5.0 \mu \mathrm{M} \alpha$-naphthalene acetic acid; after 4 weeks of incubation. $D$ - Acclimatized plantlets regenerated from $\mathrm{mT}$ mediated shoots; after 6 weeks of transfer.

Hussain et al. 2018). This increase in growth parameters in $\mathrm{mT}$ exposed explants may be due to positive signaling in dormant meristematic cells to form new shoots by upholding juvenility in plant tissues. During our studies, $\mathrm{mT}$ exposed culture showed an exuberant growth till the $12^{\text {th }}$ subculture and became stable after the $15^{\text {th }}$ subculture passage. A similar result, up to the $20^{\text {th }}$ subculture passage has been reported in Aegle marmelos (Raghu et al. 2007) without a loss of vigor to produce new shoots with no morphological or growth abnormalities.

Thus it appears that different hormonal activity is species specific. The mT exposed cultures showed threefold increase in shoot multiplication rate with abrupt increase in shoot length. The varied influence of different 
cytokinins may be attributed due to difference in genetic expression in specific plant species analyzed ( $\mathrm{Lu}$ et al. 2009).

Healthy microshoots $(\sim 5 \mathrm{~cm})$ were excised from both the types of regenerated cultures (raised on an MS with $\mathrm{mT}$ or BA) after $4^{\text {th }}$ sub-culturing and were inoculated on a half or full strength MS medium fortified with various concentrations $(1.0-7.5 \mu \mathrm{M})$ of NAA. No rooting was observed on a hormone free MS medium. However, supplementation of NAA to the full or half MS medium facilitated root induction in all tested concentrations after two weeks of incubation. Best rooting (87 \%) was observed on the half MS medium supplemented with 5.0 $\mu \mathrm{M}$ NAA in $\mathrm{mT}$ raised microshoots, with a maximum root number of $7.33 \pm 0.57$, and a root length of $6.43 \pm$ $0.06 \mathrm{~cm}$ after 6 weeks of culture (Table 4). However, microshoots raised on a medium with BA lessened the number of roots on the same NAA concentration (data not shown). An increase in root number was observed from a lower to threshold NAA concentrations, became stable and then, a decrease in root number was observed after the same incubation period. Evaluation of rooting response reveals that the half strength MS medium was better for root induction than the full strength one. Our results are in accordance with earlier reports in Sterculia urens (Hussain et al. 2008), Balanites aegyptiaca (Anis et al. 2010), and S. cumini (Naaz et al. 2014), where a reduced salt concentration supported better rhizogenesis. The MS medium augmented with NAA was found better than with other auxins in promoting best rooting in a wide range of plant species (Balaraju et al. 2009, Perveen et al. 2013).

In vitro rooting has been considered as a single phase process, in which auxins play a major role, however, during our experiments, also cytokinins were important, and the rooting frequency was much higher in $\mathrm{mT}$ than in BA raised microshoots. It was also observed that roots in $\mathrm{mT}$ raised microshoots were longer and healthier than those in BA raised plantlets. The $24 \%$ increase in rooting response observed in $\mathrm{mT}$ raised microshoots was in agreement with findings obtained in Uniola (Aremu et al. 2012b), Aloe polyphylla (Bairu et al. 2007), and Pelargonium $\times$ hortorum (Mutui et al. 2012).

Table 4. Effect of $\alpha$-naphthalene acetic acid (NAA) on in vitro rooting in meta-topolin raised shoots on a full strength and a half strength Murashige and Skoog (MS) medium after 6 weeks of incubation. Means \pm SEs, $n=3$, values denoted with different letters are significantly different $(P \leq 0.05)$ using the Duncan multiple range test.

\begin{tabular}{lllll}
\hline MS + NAA $[\mu \mathrm{M}]$ & $1 / 2 \mathrm{MS}+\mathrm{NAA}[\mu \mathrm{M}]$ & Response [\%] & Root number [shoot $\left.{ }^{-1}\right]$ & Root length $[\mathrm{cm}]$ \\
\hline 1.0 & & 35 & $2.33 \pm 0.33^{\mathrm{e}}$ & $3.83 \pm 0.16^{\mathrm{f}}$ \\
2.5 & 49 & $3.00 \pm 0.57^{\mathrm{de}}$ & $3.93 \pm 0.06^{\mathrm{de}}$ \\
5.0 & 57 & $5.33 \pm 0.33^{\mathrm{b}}$ & $5.23 \pm 0.14^{\mathrm{b}}$ \\
7.5 & 63 & $3.33 \pm 0.33^{\mathrm{de}}$ & $4.16 \pm 0.16^{\mathrm{d}}$ \\
& & 67 & $2.66 \pm 0.33^{\mathrm{de}}$ & $4.66 \pm 0.06^{\mathrm{c}}$ \\
& & $3.66 \pm 0.33^{\mathrm{cd}}$ & $4.93 \pm 0.06^{\mathrm{bc}}$ \\
& 1.0 & 87 & $7.00 \pm 0.57^{\mathrm{a}}$ & $6.43 \pm 0.06^{\mathrm{a}}$ \\
& 2.5 & $4.66 \pm 0.33^{\mathrm{bc}}$ & $5.16 \pm 0.08^{\mathrm{b}}$ \\
\hline
\end{tabular}

In micropropagation cycle, two main crucial steps are hardening and acclimatization of in vitro raised plantlets to field conditions, where the mode of nutrition changes from heterotrophic to autotrophic. The other challenging factors are changes in irradiance, air humidity, and temperature during ex vitro establishment (Pospisilova et al. 1997). The type of planting substrates also play an important role for successful and efficient establishment of tissue culture raised plantlets. We have used three different types of plant substrates, viz. garden soil, Soilrite, and Vermiculite. The highest survival rate (75\%) of regenerated plantlets was achieved on Soilrite (data no shown) due to its ideal porosity and better water holding capacity than that of garden soil and Vermiculite. Our findings are in accordance with earlier results reported by Anis et al. (2010) and Perveen et al. (2013), where regenerants show a highest survival on Soilrite. Our findings also suggest that $\mathrm{mT}$ raised plantlets were more easily acclimatized than BA raised regenerants. A similar positive effect of $\mathrm{mT}$ has been well documented in earlier reports (Bairu et al. 2007, Valero-Aracama et al. 2010, Aremu et al. 2012). Our results also show that $\mathrm{mT}$ raised regenerants had a higher number of healthy roots compared to BA raised regenerants, therefore, they were more resistant to environmental stresses in field conditions.

Antioxidant enzymes are very important for scavenging reactive oxygen species generated by stresses during acclimatization. Those are very reactive and are formed as natural byproducts of the normal metabolism of oxygen and have important roles in cell signaling and homeostasis.

The key antioxidant enzymes are SOD, APX, GR, and CAT (Mittova et al. 2003). Changes in activities of these enzymes were evaluated throughout the acclimatization process in $\mathrm{mT}$ and $\mathrm{BA}$ raised plants. The regenerants exhibited a significant increase in enzyme activities from the initial day of acclimatization up to the $35^{\text {th }}$ day 
(Table 5). Meta-topolin raised regenerants had higher activities of antioxidatnt enzymes and so a better stress tolerant capacity than BA raised regenerants. Increase in catalase levels during acclimatization phase helps to detoxify the free radical ions generated during stress conditions and easily conversion of $\mathrm{H}_{2} \mathrm{O}_{2}$ into $\mathrm{CO}_{2}$ and $\mathrm{H}_{2} \mathrm{O}$ (Scandalios. 1993, Willekens et al. 1995). Changes in CAT activity were also observed during acclimatization in Ocimum basilicum (Siddique and Anis 2008) and Tylophora indica (Faisal and Anis 2010). The role of glutathione and $\mathrm{GR}$ in $\mathrm{H}_{2} \mathrm{O}_{2}$ scavenging has been well documented in the Halliwell-Asada pathway (Asada 1999). An increase in GR activity in plants results in the accumulation of glutathione and ultimately confers stress tolerance to plants (Table 5). Malondialdehyde is a common product of lipid peroxidation and a sensitive diagnostic index of oxidative injury (Janero 1990). The production of this aldehyde is used as a biomarker to measure the level of oxidative stress (Del Rio et al. 2005). Lipid peroxidation, characterized by MDA content, and also $\mathrm{H}_{2} \mathrm{O}_{2}$ content exhibited an increasing trend till day 14 (both $\mathrm{H}_{2} \mathrm{O}_{2}$ and MDA) or $21\left(\mathrm{H}_{2} \mathrm{O}_{2}\right.$ in $\mathrm{mT}$ raised plants) and then gradually decreased (Table 5). A steep increase in $\mathrm{H}_{2} \mathrm{O}_{2}$ content was observed in the plantlets during early days of acclimatization, with a maximum increment of $50.4 \%$ in $\mathrm{mT}$ raised regenerants and $21.4 \%$ in BA raised regenerants at day 21 . Proline is an amino acid which is a major signaling molecule and plays a beneficial role when plants are exposed to various stresses. It is an excellent osmolyte and prevents oxidative burst in plants. Meta-topolin raised regenerants showed a higher increase in proline content (up to $70.48 \%$ ) during acclimatization than BA raised regenerats (up to $55.55 \%$ ) (Table 5). An enhanced lipid peroxidation in $\mathrm{mT}$ raised regenerants than in $\mathrm{BA}$ regenerants regenerants, as indicated by a higher MDA and $\mathrm{H}_{2} \mathrm{O}_{2}$ content, indicates a higher oxidative stress. However, they had higher activities of all antioxidative enzymes.

Table 5. Changes in super oxide dismutase (SOD), glutathione reductase (GR), catalase (CAT), and ascorbate peroxidase (APX) activities $\left[\mu \mathrm{mol} \mathrm{mg} \mathrm{mg}^{-1}\right.$ (protein) $\left.\mathrm{min}^{-1}\right]$ as well as $\mathrm{H}_{2} \mathrm{O}_{2}$, proline, and malondialdehyde (MDA) content $\left[\mu \mathrm{g} \mathrm{g}^{-1}\right.$ (f.m.) $]$ in the meta-topolin $(\mathrm{mT})$ and benzyladenine (BA) raised regenerants during acclimatization periods $(0,7,14,21,28$, and $35 \mathrm{~d})$. Means $\pm \mathrm{SEs}, n=3$, values denoted with different letters are significantly different $(P \leq 0.05)$ using the Duncan multiple range test.

\begin{tabular}{|c|c|c|c|c|c|c|c|}
\hline Parameter & Cytokinin & $0 \mathrm{~d}$ & $7 \mathrm{~d}$ & $14 \mathrm{~d}$ & $21 \mathrm{~d}$ & $28 \mathrm{~d}$ & $35 \mathrm{~d}$ \\
\hline \multirow[t]{2}{*}{ SOD } & BA & $0.73 \pm 0.04_{\mathrm{fg}}$ & $0.92 \pm 0.22_{\mathrm{f}}$ & $1.72 \pm 0.41_{\mathrm{def}}$ & $2.54 \pm 0.02_{\mathrm{cd}}$ & $2.89 \pm 0.01 \mathrm{bcd}$ & $4.12 \pm 0.02_{\mathrm{a}}$ \\
\hline & $\mathrm{mT}$ & $0.83 \pm 0.02_{\mathrm{f}}$ & $1.24 \pm 0.32 \mathrm{de}$ & $1.99 \pm 0.02_{\mathrm{d}}$ & $3.47 \pm 0.05_{\mathrm{c}}$ & $4.91 \pm 0.03 \mathrm{bc}$ & $6.16 \pm 0.04_{a}$ \\
\hline \multirow[t]{2}{*}{ GR } & $\mathrm{BA}$ & $1.12 \pm 0.03_{\mathrm{f}}$ & $1.92 \pm 0.02 \mathrm{e}$ & $2.84 \pm 0.03_{\mathrm{cd}}$ & $2.96 \pm 0.03_{\mathrm{cd}}$ & $3.82 \pm 0.03 \mathrm{~b}$ & $4.34 \pm 0.04_{\mathrm{ab}}$ \\
\hline & $\mathrm{mT}$ & $1.51 \pm 0.41_{\mathrm{i}}$ & $2.63 \pm 0.042_{\mathrm{gh}}$ & $3.79 \pm 0.01_{\mathrm{ef}}$ & $4.91 \pm 0.01_{\mathrm{cde}}$ & $5.82 \pm 0.82 \mathrm{bcd}$ & $6.44 \pm 0.02 \mathrm{a}$ \\
\hline \multirow[t]{2}{*}{ CAT } & BA & $5.21 \pm 0.28 \mathrm{hi}$ & $7.88 \pm 0.09_{\mathrm{fgh}}$ & $9.12 \pm 0.08_{\text {efg }}$ & $16.12 \pm 0.02 \mathrm{~cd}$ & $22.34 \pm 0.02 b$ & $25.37 \pm 0.03 \mathrm{ab}$ \\
\hline & $\mathrm{mT}$ & $9.89 \pm 0.02 \mathrm{~g}$ & $13.45 \pm 0.06_{\mathrm{ef}}$ & $17.56 \pm 0.02 \mathrm{~d}$ & $24.26 \pm 0.03 \mathrm{bcd}$ & $26.88 \pm 0.06 \mathrm{~b}$ & $30.34 \pm 0.02 \mathrm{a}$ \\
\hline \multirow[t]{2}{*}{ APX } & BA & $0.18 \pm 0.08 \mathrm{~h}$ & $0.37 \pm 0.32 \mathrm{fg}$ & $0.46 \pm 0.09_{\mathrm{def}}$ & $0.58 \pm 0.06_{\text {cde }}$ & $0.62 \pm 0.30 \mathrm{bc}$ & $0.99 \pm 0.21_{\mathrm{ab}}$ \\
\hline & $\mathrm{mT}$ & $0.33 \pm 0.23 \mathrm{fg}$ & $0.41 \pm 0.12 \mathrm{defg}$ & $0.66 \pm 0.11_{\mathrm{de}}$ & $0.83 \pm 0.13 \mathrm{bc}$ & $0.97 \pm 0.33 \mathrm{~b}$ & $1.78 \pm 0.32 \mathrm{a}$ \\
\hline \multirow[t]{2}{*}{$\mathrm{H}_{2} \mathrm{O}_{2}$} & BA & $3.57 \pm 0.23_{\text {ef }}$ & $3.88 \pm 0.18 \mathrm{~cd}$ & $4.77 \pm 0.18 \mathrm{ab}$ & $4.08 \pm 0.21 \mathrm{bc}$ & $3.62 \pm 0.22 \mathrm{de}$ & $3.88 \pm 0.22 \mathrm{~cd}$ \\
\hline & $\mathrm{mT}$ & $3.91 \pm 0.32_{\mathrm{ijk}}$ & $5.28 \pm 0.33_{\mathrm{ghi}}$ & $7.14 \pm 0.23 \mathrm{~cd}$ & $7.89 \pm 0.22 \mathrm{ab}$ & $6.80 \pm 0.20 \mathrm{def}$ & $6.55 \pm 0.33_{\mathrm{ef}}$ \\
\hline \multirow[t]{2}{*}{ Proline } & BA & $0.91 \pm 0.31_{\mathrm{gh}}$ & $1.01 \pm 0.01_{\mathrm{fg}}$ & $1.29 \pm 0.32_{\mathrm{f}}$ & $1.53 \pm 0.23_{\mathrm{cde}}$ & $1.68 \pm 0.22 \mathrm{bc}$ & $1.99 \pm 0.12 \mathrm{ab}$ \\
\hline & $\mathrm{mT}$ & $1.01 \pm 0.22 \mathrm{gh}$ & $1.11 \pm 0.04_{\mathrm{fg}}$ & $1.51 \pm 0.05_{\mathrm{f}}$ & $2.18 \pm 0.02_{\text {cde }}$ & $2.97 \pm 0.03 \mathrm{bc}$ & $3.38 \pm 0.04_{\mathrm{a}}$ \\
\hline \multirow[t]{2}{*}{ MDA } & $\mathrm{BA}$ & $3.02 \pm 0.62_{\mathrm{hijk}}$ & $4.89 \pm 0.04_{\mathrm{def}}$ & $5.81 \pm 0.43_{\mathrm{ab}}$ & $5.65 \pm 0.23 \mathrm{bc}$ & $5.05 \pm 0.35_{\mathrm{cde}}$ & $4.01 \pm 0.64_{\text {fgh }}$ \\
\hline & $\mathrm{mT}$ & $6.12 \pm 0.45_{\mathrm{jk}}$ & $8.71 \pm 0.02_{\mathrm{cd}}$ & $9.11 \pm 0.71_{\mathrm{ab}}$ & $8.44 \pm 0.71_{\mathrm{def}}$ & $8.10 \pm 0.56_{\mathrm{fgh}}$ & $7.89 \pm 0.54_{\mathrm{ghi}}$ \\
\hline
\end{tabular}

In conclusion, addition of $\mathrm{mT}$ into an MS medium is a much better option than addition of other cytokinins for in vitro growth and morphogenesis in S. cumini using nodal explants. Further, mT regenerated shoots rooted and acclimatized very easily with a higher survival rate as compared to BA mediated ones. Since in vitro culture has emerged as a useful strategy for producing plant derived pharmaceuticals, the results obtained may be useful to improve the efficiency of the process and would also be effective for other recalcitrant tree species.

\section{References}

Aebi, H.: Catalase in vitro. - Methods Enzymol. 105: 121-126, 1984.

Ahmad, N., Javed, S.B., Khan, M.I., Anis, M.: Rapid plant regeneration and analysis of genetic fidelity in micropropagated plants of Vitex trifolia: an important medicinal plant. - Acta. Physiol. Plant. 35: 2493-2500, 2013.
Alexieva, V., Sergiev, I., Mapelli, S., Karanov. E.: The effect of drought and UV on growth and stress markers in pea and wheat. - Plant Cell Environ 24: 1337-1344, 2001.

Amoo, S., Finnie, J.F., Van Staden.: The role of meta-topolins in alleviating micropropagation problems. - Plant Growth Regul. 63: 197-206, 20011. 
Anis, M., Varshney, A., Siddique, I.: In vitro clonal propagation of Balanites aegyptiaca (L.) Del. - Agroforest. Syst. 78: 151-158, 2010

Aremu, A.O., Bairu M.W., Szucova, L., Dolezal, K., Finnie J.F.: Assessment of the role of meta-topolins on in vitro produced phenolics and acclimatization competence of micropropagated 'Williams' banana -. Acta Physiol. Plant. 34: 2265-2273, 2012.

Asada, K.: The water-water cycle in chloroplasts: scavenging of active oxygen and dissipation of excess photons. - Annu. Rev. Plant Physiol. Plant. mol. Biol. 50: 601-639, 1999.

Bairu, M.W., Stirk, W.A., Dolezal, K., Staden, J.V.: Optimizing the micropropagation protocol for the endangered Aloe polyphylla: can meta-topolin and its derivatives serve as replacement for benzyl adenine and zeatin? - Plant Cell Tissue Organ Cult. 90: 15-23, 2007.

Bairu, M.W., Stirk, W.A., Dolezal, K., Van Staden, J.: The role of topolins in micropropagation and somaclonal variation of banana cultivars 'Williams' and 'Grand Naine' (Musa spp. AAA). - Plant Cell Tissue Organ Cult. 95: 373-379, 2008.

Balaraju, K., Agastian, K., Ignacimuthu, S.: Micropropagation of Swertia chirata Buch.-Hams. ex Wall: a critically endangered medicinal herb. - Acta. Physiol. Plant 31: 487494, 2009.

Bergmeyer, H.U., Gawehn, K., Grassi, M.: Enzymes as biochemical reagents. - In: Bergmeyer, H.U. (ed.): Methods in Enzymatic Analysis. Pp. 425-522. Academic Press, New York 1974.

Cakmak, I., Horst, J.H.: Effect of aluminium on lipid peroxidation, superoxide dismutase, catalase and peroxidase activities in root tips of soybean (Glycine max). - Physiol. Plant 83: 463-468, 1991.

Carillo, P., Mastrolonardo, G., Nacca, F., Parisi, D., Verlotta, A., Fuggi, A.: Nitrogen metabolism in durum wheat under salinity: accumulation of proline and glycine betaine. Funct. Plant Biol. 35: 412-426, 2008.

Del Rio, D., Stewart, A.J., Pellegrini, N.: A review of recent studies on malondialdehyde as toxic molecule and biological marker of oxidative stress. - Nutr. Metabol. Cardiovasc. Dis. 14: 316-328, 2005.

Dhindsa, R. S., Plumb-Dhindsa, P., Thorp, T.A.: Leaf senescence: correlated with increased levels of membrane permeability and lipid peroxidation and decreased levels of superoxide dismutase and catalase. - J. exp. Bot. 32: 93-101, 1981.

Faisal, M., Anis, M.: Effect of light irradiances on photosynthetic machinery and antioxidant enzymes during ex vitro acclimatization of Tylophora indica plantlets. - J. Plant Interact. 5: 21-27, 2010.

Foyer, C.H., Mullineaux, P.M. Causes of Oxidative Stress and Amelioration of Defense Systems in Plants. - CRC Press, Boca Raton, 1994.

Gentile, A., Gutiérrez, M.J., Martinez, J., Frattarelli, A., Nota, P., Caboni, E.: Effect of meta-topolin on micropropagation and adventitious shoot regeneration in Prunus rootstocks. Plant Cell Tissue Organ Cult. 118: 373-381, 2014.

Hussain, S.A., Ahmad, N., Anis, M.: Synergetic effect of TDZ and BA on minimizing the post-exposure effects on axillary shoot proliferation and assessment of genetic fidelity in Rauvolfia tetraphylla (L.). - Rend. Lincei Fis. Natur. 29: 109-115, 2018.

Jain, N., Babbar, S.B.: Recurrent production of plants of black plum, Syzygium cumini (L.) Skeels, a myrtaceous fruit tree from in vitro cultured seedling explants. - Plant Cell Rep. 19: 519-524, 2000.

Janero, D.R.: Malondialdehyde and thiobarbituric acidreactivity as diagnostic indices of lipid peroxidation and peroxidative tissue injury. - Free Radicals Biol. Med. 9: 515-540, 1990.

Koszeghi, S., Bereczki, C., Balog, A., Benedek, K.: Comparing the effects of benzyladenine and meta-topolin on sweet basil (Ocimum basilicum) micropropagation. - Notes Sci. Biol. 6: 422-427, 2014.

Lu, Y., Huggins, P., Bar-Joseph, Z.: Cross species analysis of microarray expression data. - Bioinformatics 25: 14761483,2009

Mittova, V., Tal, M., Volokita, M., Guy, M.: Up-regulation of the leaf mitochondrial and peroxisomal systems in response to salt-induced oxidative stress in the wild salt-tolerant tomato species Lycopersicon pennellii. - Plant Cell Environ. 26: 845-856, 2003.

Murashige, T., Skoog, M.: A revised medium for rapid growth and bioassays with tobacco tissue cultures. - Physiol. Plant. 15: 473-497, 1962.

Mutui, T.M., Mibus, H., Serek, M.: Effect of meta-topolin on leaf senescence and rooting in Pelargonium $\times$ hortorum cuttings. - Post Harv. Biol. Technol. 63: 107-110, 2012.

Naaz, A., Shahzad, A., Anis, M.: Effect of adenine sulphate interaction on growth and development of shoot regeneration and inhibition of shoot tip necrosis under invitro condition in adult Syzygium cumini L. - a multipurpose tree. - Appl. Biochem. Biotechnol. 173: 90102, 2014.

Perveen, S., Javed, S.B., Anis, M., Aref, I.M.: Rapid in vitro multiplication and ex vitro establishment of Caribbean copper plant (Euphorbia cotinifolia L.): an important medicinal shrub. - Acta. Physiol. Plant. 35: 3391-3400, 2013.

Pospíšilová, J., Čatský, J., Šesták, Z.: Photosynthesis in plants cultivated in vitro. - In: Pessarakli, M. (ed.): Handbook of Photosynthesis. Pp. 525-540. Marcel Dekker, New York Basel - Hong Kong 1997.

Raghu, A.V., Geetha, S.P., Martin, G., Balachandran, I., Ravindran, P.N., Mohanan, K.V.: An improved micropropagation protocol for bael - a vulnerable medicinal tree. - Res. J. Bot. 2: 186-194, 2007.

Rao, M.V.: Cellular detoxifying mechanisms determine age dependent injury in tropical plants exposed to $\mathrm{SO}_{2}$. - J. Plant Physiol. 140: 733-740, 1992.

Rathore, V., Shekhawat, N.S., Singh, R.P., Rathore, J.S., Daglen, H.R.: Cloning of adult trees of jamun (Syzigium cumini). - Indian J. Biotechnol. 3: 254-264, 2004.

Salvi, N.D., George, L., Susan, E.: Micropropagation and field evaluation of micropropagated plants of turmeric. - Plant Cell Tissue Organ Cult. 62: 143-151, 2002.

Scandalios, J.G.: Oxygen stress and superoxide dismutase. Plant Physiol. 101: 7-12, 1993.

Siddique, I., Anis, M.: An improved plant regeneration system and ex vitro acclimatization of Ocimum basilicum L. - Acta Physiol. Plant. 30: 493-499, 2008.

Valero-Aracama, C., Kane, M. E., Wilson, S. B., Philman, N. L.: Substitution of benzyladenine with meta-topolin during shoot multiplication increases acclimatization of difficultand easy-to-acclimatize sea oats (Uniola paniculata L.) genotypes. - Plant Growth Regul. 60: 43-49, 2010.

Werbrouck, S.P.O., Strnad, M., Van-Onckelen, H.A., Debergh, 
P.C.: Meta-topolin, an alternative to benzyladenine in tissue culture? - Physiol. Plant. 98: 291-297, 1996.

Willekens, H., Inze, D., Van Montagu, M., Van Camp, W.: Catalases in plants. - Mol. Breed. 1: 207-228, 1995.
Yadav, U., Lal, M., Jaiwal, V.S.: In vitro micropropagation of tropical fruit tree Syzigium cuminii L. - Plant Cell Tissue Organ Cult. 21: 87-92, 1990. 